\title{
Sulfur Dioxide Enhances Endogenous Hydrogen Sulfide Accumulation and Alleviates Oxidative Stress Induced by Aluminum Stress in Germinating Wheat Seeds
}

\author{
Dong-Bo Zhu, ${ }^{1}$ Kang-Di Hu, ${ }^{1}$ Xi-Kai Guo, ${ }^{1}$ Yong Liu, ${ }^{1}$ Lan-Ying Hu, \\ Yan-Hong Li, ${ }^{1}$ Song-Hua Wang, ${ }^{2}$ and Hua Zhang ${ }^{1}$ \\ ${ }^{1}$ School of Biotechnology and Food Engineering, Hefei University of Technology, Hefei 230009, China \\ ${ }^{2}$ Life Science College, Anhui Science and Technology University, Bengbu 233100, China \\ Correspondence should be addressed to Hua Zhang; hzhanglab@gmail.com
}

Received 28 October 2014; Accepted 21 November 2014

Academic Editor: Guangdong Yang

Copyright (c) 2015 Dong-Bo Zhu et al. This is an open access article distributed under the Creative Commons Attribution License, which permits unrestricted use, distribution, and reproduction in any medium, provided the original work is properly cited.

\begin{abstract}
Aluminum ions are especially toxic to plants in acidic soils. Here we present evidences that $\mathrm{SO}_{2}$ protects germinating wheat grains against aluminum stress. $\mathrm{SO}_{2}$ donor $\left(\mathrm{NaHSO}_{3} / \mathrm{Na}_{2} \mathrm{SO}_{3}\right)$ pretreatment at $1.2 \mathrm{mM}$ reduced the accumulation of superoxide anion, hydrogen peroxide, and malondialdehyde, enhanced the activities of guaiacol peroxidase, catalase, and ascorbate peroxidase, and decreased the activity of lipoxygenase in germinating wheat grains exposed to $\mathrm{Al}$ stress. We also observed higher accumulation of hydrogen sulfide $\left(\mathrm{H}_{2} \mathrm{~S}\right)$ in $\mathrm{SO}_{2}$-pretreated grain, suggesting the tight relation between sulfite and sulfide. Wheat grains geminated in water for $36 \mathrm{~h}$ were pretreated with or without $1 \mathrm{mM} \mathrm{SO}_{2}$ donor for $12 \mathrm{~h}$ prior to exposure to $\mathrm{Al}$ stress for $48 \mathrm{~h}$ and the ameliorating effects of $\mathrm{SO}_{2}$ on wheat radicles were studied. $\mathrm{SO}_{2}$ donor pretreatment reduced the content of reactive oxygen species, protected membrane integrity, and reduced $\mathrm{Al}$ accumulation in wheat radicles. Gene expression analysis showed that $\mathrm{SO}_{2}$ donor pretreatment decreased the expression of Al-responsive genes TaWalil, TaWali2, TaWali3, TaWali5, TaWali6, and TaALMT1 in radicles exposed to $\mathrm{Al}$ stress. These results suggested that $\mathrm{SO}_{2}$ could increase endogenous $\mathrm{H}_{2} \mathrm{~S}$ accumulation and the antioxidant capability and decrease endogenous $\mathrm{Al}$ content in wheat grains to alleviate $\mathrm{Al}$ stress.
\end{abstract}

\section{Introduction}

Aluminum ions $\left(\mathrm{Al}^{3+}\right)$ together with silicon and iron are the three most abundant mineral elements in soil. Whereas silicon and iron are required for plant growth, $\mathrm{Al}$ is toxic. Many different mechanisms have been advanced to explain $\mathrm{Al}$ toxicity in plants $[1,2]$. One of the primary causes of $\mathrm{Al}$ toxicity is oxidative stress due to accumulation of reactive oxygen species (ROS), such as the superoxide anion $\left(\mathrm{O}_{2}{ }^{--}\right)$ and hydrogen peroxide $\left(\mathrm{H}_{2} \mathrm{O}_{2}\right)$, bringing about lipid peroxidation in plant cells [3-5]. Plants have developed several strategies to counteract oxidative stress caused by $\mathrm{Al}$, such as activation of antioxidants, and exudation of organic acids as a mechanism for $\mathrm{Al}$ exclusion [6]. Recently, a range of signaling molecules, such as inositol 1,4,5-triphosphate $\left(\mathrm{IP}_{3}\right)$, salicylic acid, hydrogen peroxide $\left(\mathrm{H}_{2} \mathrm{O}_{2}\right)$ and nitric oxide
(NO), carbon monoxide (CO), and hydrogen sulfide $\left(\mathrm{H}_{2} \mathrm{~S}\right)$, were found to participate in plant's resistance to $\mathrm{Al}$-induced oxidative stress $[4,7-10]$.

Sulfur dioxide $\left(\mathrm{SO}_{2}\right)$ is a colorless, nonflammable gas with a penetrating odor. Low concentrations of $\mathrm{SO}_{2}$ have been found to play a physiological role in vivo in animal models, participating in various biological processes [11]. The physiological processes regulated by $\mathrm{SO}_{2}$ in animals include cardiac function [11], inhibition of L-calcium channels in cardiomyocytes [12], and improvement in pulmonary vascular structural remodeling [13]. In plants, the toxic effects of $\mathrm{SO}_{2}$ on growth and development have been extensively studied $[14,15]$. Exposure to high concentrations of $\mathrm{SO}_{2}$ can cause visible foliar damage, a decline in photosynthesis, an inhibition of plant growth, and structural disorganization and cell death [16-19]. On the other hand, many reports show 
that low levels of atmospheric $\mathrm{SO}_{2}$ might be beneficial to plants [20]. $\mathrm{SO}_{2}$ can be metabolized and used as a sulfur source for plant growth, especially when the sulfur supply in soil is insufficient for normal growth [20]. Recently, low concentrations of $\mathrm{SO}_{2}$ were found to induce transcriptome reprogramming associated with oxidative signaling and biotic defence responses in plants, suggesting a physiological role of $\mathrm{SO}_{2}$ in plant [21].

In plants, sulfate is taken up from soil by high-affinity transporters. Sulfate is largely transported to shoots where it can be activated by ATP via ATP sulfurylase in the leaves. The product is reduced by $5^{\prime}$-adenylylsulfate (APS) reductase to sulfite which can be reduced to $\mathrm{H}_{2} \mathrm{~S}$ by sulfite reductase [22]. $\mathrm{SO}_{2}$ can also be produced endogenously from sulfurcontaining amino acids [23]. The endogenous production of $\mathrm{SO}_{2}$ also suggests that it has a physiological role in plants.

In order to establish the role of $\mathrm{SO}_{2}$ in alleviating $\mathrm{Al}$ stress, we investigated the effects of $\mathrm{SO}_{2}$ pretreatment on $\mathrm{H}_{2} \mathrm{~S}$ and ROS accumulation and the antioxidant system in whole wheat grains and in wheat radicles. We also analyzed endogenous $\mathrm{H}_{2} \mathrm{~S}$ and $\mathrm{Al}$ content as a means of understanding the mechanism of the role of $\mathrm{SO}_{2}$. We speculated that $\mathrm{SO}_{2}$ might act as an antioxidant molecule to alleviate Al toxicity during wheat grain germination.

\section{Materials and Methods}

2.1. Materials and Treatments. Wheat (Triticum aestivum L.) grains were supplied by the Anhui Aidi Agricultural Technology Co., Ltd., Anhui Province, China. Sodium bisulfite $\left(\mathrm{NaHSO}_{3}\right)$ and anhydrous sodium sulfite $\left(\mathrm{Na}_{2} \mathrm{SO}_{3}\right)$ were used as sulfur dioxide $\left(\mathrm{SO}_{2}\right)$ donors according to Laisk et al. [24]. Wheat grains were sterilized by $0.1 \% \mathrm{HgCl}_{2}$ for 3 min and washed extensively with $\mathrm{H}_{2} \mathrm{O}$ and then dried with filter papers. Wheat grains of similar size were selected and allocated randomly in Petri dish $(9 \mathrm{~cm}$ diameter $\times 1.2 \mathrm{~cm}$ depth, 50 grains per dish). Wheat grains were germinated in $\mathrm{H}_{2} \mathrm{O}$ or aqueous solutions of $\mathrm{AlCl}_{3}$ at $5,10,15,20,25$, 30,60 , and $90 \mathrm{mM}$ for $48 \mathrm{~h}$ at $25^{\circ} \mathrm{C}$ and the length of coleoptiles and radicles and radicle number were recorded. To test the protective role of $\mathrm{SO}_{2}$ on germination and seedling growth of wheat grains under $\mathrm{Al}$ stress, grains were pretreated with $\mathrm{H}_{2} \mathrm{O}$ or $0.4,0.8,1.2,1.6$, or $2.0 \mathrm{mM} \mathrm{SO}_{2}$ donor for $12 \mathrm{~h}$ and subsequently subjected to a semi-inhibitory $\mathrm{AlCl}_{3}$ concentration $(15 \mathrm{mM}) . \mathrm{AlCl}_{3}$ solutions were renewed every $12 \mathrm{~h}$ and geminating grains were sampled every $12 \mathrm{~h}$ for further analysis.

2.2. Determination of $\mathrm{MDA}, \mathrm{O}_{2}{ }^{\bullet-}$, and $\mathrm{H}_{2} \mathrm{O}_{2}$. The contents of $\mathrm{MDA}, \mathrm{O}_{2}{ }^{--}$, and $\mathrm{H}_{2} \mathrm{O}_{2}$ were determined by the method of Zhang et al. [25].

2.3. Assays of LOX, CAT, APX, and POD Activities. Activity of lipoxygenase (LOX, EC 1.13.11.12) was determined following the description by Surrey [26] and those of catalase (CAT, EC1.11.1.6), ascorbate peroxidase (APX, EC 1.11.1.11), and guaiacol peroxidase (POD, EC 1.11.1.7) were assayed according to $\mathrm{Hu}$ et al. [27]. Wheat grains were homogenized in ice-cold
$50 \mathrm{mM}$ phosphate buffer ( $\mathrm{pH} 7.8$ ) containing $1.0 \mathrm{mM}$ EDTA. The homogenate was centrifuged at $15,000 \mathrm{~g}$ at $4^{\circ} \mathrm{C}$ for $10 \mathrm{~min}$. The supernatant was used for activity determination.

2.4. Assays of Reducing Sugars and Soluble Protein. Wheat grains $(0.5 \pm 0.05 \mathrm{~g})$ were ground in $5 \mathrm{~mL}$ of phosphate buffer ( $\mathrm{pH} 7.0,200 \mathrm{mM})$, the homogenate was centrifuged at $10,000 \mathrm{~g}$ for $30 \mathrm{~min}$, and the supernatant was used for detection of reducing sugars and soluble protein content. Reducing sugar content was measured according to Miller [28].

For detection of soluble protein, $0.1 \mathrm{~mL}$ supernatant was mixed with $0.9 \mathrm{~mL} \mathrm{H}_{2} \mathrm{O}$ and $5 \mathrm{~mL}$ Coomassie brilliant blue for $5 \mathrm{~min}$ and the absorbance recorded at $595 \mathrm{~nm}$ using the method described by Bradford [29].

2.5. Preparation of Wheat Radicles. Wheat grains were geminated in $\mathrm{H}_{2} \mathrm{O}$ for $36 \mathrm{~h}$ in the dark at $25^{\circ} \mathrm{C}$ and the average of radicle length was approximately $1.0 \mathrm{~cm}$. The geminated wheat grains were pretreated with or without $1 \mathrm{mM} \mathrm{SO}$ donor for $12 \mathrm{~h}$ and then exposed to 0 or $400 \mu \mathrm{M} \mathrm{AlCl}$ for $48 \mathrm{~h}$.

2.6. Detection of Plasma Membrane Integrity, Al Accumulation, and ROS Production in Radicles. Plasma membrane integrity of wheat radicles was detected following the method of Yamamoto et al. [30]. Radicles were stained with Evans blue solution $(0.025 \%[\mathrm{w} / \mathrm{v}]$ Evans blue in $100 \mu \mathrm{M} \mathrm{CaCl}$, $\mathrm{pH}$ 5.6) for $10 \mathrm{~min}$, then washed three times with $100 \mu \mathrm{M}$ $\mathrm{CaCl}_{2}$ solutions, and photographed. Staining intensity of Evans blue is positively correlated with more damaged plasma membrane.

Al content in radicles was visualized by staining tissues with hematoxylin. Hematoxylin stain was prepared as described by Polle et al. [31]. Wheat radicles were washed with $\mathrm{H}_{2} \mathrm{O}$ for $30 \mathrm{~min}$ and then stained with solution of $0.2 \%$ hematoxylin and $0.02 \% \mathrm{NaIO}_{3}$ for $30 \mathrm{~min}$ at room temperature. Radicles were then immersed in $\mathrm{H}_{2} \mathrm{O}$ for $30 \mathrm{~min}$ to remove excess stain and photographed. Staining intensity of hematoxylin is positively correlated with Al uptake.

ROS distribution in radicle tips was detected by $2^{\prime}, 7^{\prime}$ dichlorofluorescin diacetate (DCFH-DA) following the method of LeBel et al. [32]. Radicle tips were incubated in a solution containing $100 \mu \mathrm{M} \mathrm{CaCl}_{2}$ and $10 \mu \mathrm{M}$ DCFH-DA for $20 \mathrm{~min}$ and then washed three times with $\mathrm{H}_{2} \mathrm{O}$. The fluorescence was detected with a Nikon 80i microscope (excitation at $488 \mathrm{~nm}$ and emission at $525 \mathrm{~nm}$ ). For each treatment, ten individual roots from ten seedlings were examined and similar results were obtained.

2.7. Real-Time Quantitative RT-PCR Analysis in Wheat Radicles. Radicle tips were prepared for RNA extraction according to $\mathrm{Li}$ et al. [33]. Total RNA was isolated by grinding with liquid nitrogen according to the manufacturer's instructions (CWBIO, Beijing, China). cDNA was generated from total RNA with a reverse transcription kit (Prime Script RT Master Mix, Takara, Kyoto, Japan). Quantitative PCR was performed using a StepOnePlus Real-Time PCR 
TABLE 1: Inhibitory effect of Al stress on the germination of wheat grains. Wheat grains were exposed to $0,5,10,15,20,25,30,60$, or $90 \mathrm{mM}$ $\mathrm{AlCl}_{3}$ for $48 \mathrm{~h}$.

\begin{tabular}{|c|c|c|c|c|}
\hline $\mathrm{Al}^{3+}$ concentration $(\mathrm{mM})$ & Germination percentage (\%) & Radicle length $(\mathrm{cm})$ & Coleoptile length $(\mathrm{cm})$ & Radicle number (50 grains) \\
\hline 0 & $64 \pm 1.2^{\mathrm{a}}$ & $3.1 \pm 0.8^{\mathrm{a}}$ & $1.5 \pm 0.3^{\mathrm{ab}}$ & $178 \pm 7.8^{\mathrm{a}}$ \\
\hline 5 & $66 \pm 1.1^{\mathrm{a}}$ & $2.7 \pm 0.5^{\mathrm{ab}}$ & $1.6 \pm 0.2^{\mathrm{a}}$ & $168 \pm 8.9^{\mathrm{a}}$ \\
\hline 10 & $51 \pm 2.3^{\mathrm{b}}$ & $1.9 \pm 0.3^{b}$ & $1.3 \pm 0.3^{\mathrm{ab}}$ & $162 \pm 7.6^{\mathrm{a}}$ \\
\hline 15 & $35 \pm 3.8^{\mathrm{c}}$ & $1.1 \pm 0.2^{\mathrm{c}}$ & $1.1 \pm 0.2^{\mathrm{bc}}$ & $142 \pm 6.3^{\mathrm{b}}$ \\
\hline 20 & $28 \pm 4.2^{\mathrm{cd}}$ & $0.7 \pm 0.3^{\mathrm{cd}}$ & $0.8 \pm 0.2^{\mathrm{cd}}$ & $80 \pm 5.6^{c}$ \\
\hline 25 & $21 \pm 5.1^{\mathrm{de}}$ & $0.4 \pm 0.3^{\mathrm{d}}$ & $0.6 \pm 0.2^{\mathrm{de}}$ & $68 \pm 6.1^{\mathrm{c}}$ \\
\hline 30 & $15 \pm 4.7^{\mathrm{ef}}$ & $0.2 \pm 0.2^{\mathrm{d}}$ & $0.3 \pm 0.3^{\mathrm{e}}$ & $45 \pm 5.3^{\mathrm{d}}$ \\
\hline 60 & $8 \pm 5.2^{\mathrm{f}}$ & $0.1 \pm 0.1^{\mathrm{d}}$ & $0.3 \pm 0.2^{\mathrm{e}}$ & $22 \pm 3.5^{\mathrm{e}}$ \\
\hline 90 & $7 \pm 6.3^{\mathrm{f}}$ & $0 \pm 0^{\mathrm{e}}$ & $0.2 \pm 0.2^{\mathrm{e}}$ & $0 \pm 0^{\mathrm{f}}$ \\
\hline
\end{tabular}

Values are the means $\pm \mathrm{SD}(n=6)$. Values are the means $\pm \mathrm{SD}(n=6)$. Different letters mean significance of difference between different treatments $(P<$ $0.05)$.

System (Applied Biosystems, Foster City, CA, USA) with SYBR Premix Ex Taq (TaKaRa Bio Inc., China) according to the manufacturer's instructions. cDNA was amplified by PCR using the following primers: $\mathrm{Ta} \beta$-actin forward $\left(5^{\prime}-\right.$ CTATCCTTCGTTTGGACCTT- $\left.3^{\prime}\right)$ and reserve $\left(5^{\prime}\right.$-AGCGAGCTTCTCCTTTATGT- $\left.{ }^{\prime}\right)$; TaWalil forward (5'-CTGATGGAGTCGAGCAAGG- $\left.3^{\prime}\right)$ and reserve $\left(5^{\prime}\right.$-CCGAAGTAGCGATTTAGGAGT-3 $\left.{ }^{\prime}\right)$; TaWali2 forward $\left(5^{\prime}\right.$-AGCCTACTGCTCCGCCTTGT- $\left.3^{\prime}\right)$ and reserve (5'-CGTTTCGTCGGCATCTCC- $\left.3^{\prime}\right)$; TaWali3 forward (5'-GACGAGCCCTAAGAAGACG- $\left.3^{\prime}\right)$ and reserve (5'-CACGGAGCAATGACAACAG-3'); TaWali5 forward (5'-TGGACCCTGCAAGAAGTAC- $\left.3^{\prime}\right)$ and reserve (5'-GCTGAACAACAAGCAACACC- $3^{\prime}$ ); TaWali6 forward (5' -TACGGAATAGACAGGACAAGG- $3^{\prime}$ ) and reserve $\left(5^{\prime}\right.$-CAGCATTTCGGGAACTCG-3 ${ }^{\prime}$ ); TaALMT1 forward ( $5^{\prime}$-TGCCACGCTGAGTAAAGG- $\left.3^{\prime}\right)$ and reserve $\left(5^{\prime}\right.$-CGCTGACGCTACGAAGAA- $\left.3^{\prime}\right)$. Relative gene expression was presented as values relative to the corresponding gene expression in control, after normalization to the control Ta $\beta$-actin transcript levels.

2.8. Statistical Analysis. Statistical significance was tested by one-way ANOVA, and the results are expressed as the mean values \pm SD (standard deviation) of three independent experiments. Each experiment was repeated three times.

\section{Results}

3.1. Inhibitory Effect of Al on Wheat Grain Germination. The effect of $\mathrm{Al}$ stress on wheat seedling growth and development was examined following incubation of grain in $\mathrm{AlCl}_{3}$ with concentrations ranging from $5 \mathrm{mM}$ to $90 \mathrm{mM}$ (Table 1). At concentrations of $5 \mathrm{mM}$ or below, germination percentage, coleoptile length, and radicle number are almost unaffected, but radicle length was reduced by $13 \%$, suggesting that the radicle is the primary target of $\mathrm{Al}$ toxicity. At $15 \mathrm{mM}$ $\mathrm{Al}$, germination percentage was almost halved compared with that of control and this concentration was selected for further experiments. At $90 \mathrm{mM} \mathrm{Al}$, radicle growth was completely inhibited, but very stunted coleoptile growth was still observed.
3.2. $\mathrm{SO}_{2}$ Donor Ameliorates Al Stress in Germinating Wheat Grain. To establish whether the $\mathrm{SO}_{2}$ donor $\mathrm{Na}_{2} \mathrm{SO}_{3} /$ $\mathrm{NaHSO}_{3}$ had a toxic effect on wheat grain germination, grains were germinated in different $\mathrm{SO}_{2}$ donor concentrations ranging from 0.4 to $2.0 \mathrm{mM}$ for $36 \mathrm{~h}$ (see Table S1 in Supplementary Material available online at http://dx.doi.org/ $10.1155 / 2015 / 612363)$. Table S1 shows there was no significant change in germination percentage, coleoptile length, radicle length, or radicle number between water control and $\mathrm{SO}_{2}$ donor treatment, establishing that the concentrations of $\mathrm{SO}_{2}$ donor used in this work exhibited no visible toxic effects. To test the ability of $\mathrm{SO}_{2}$ donor to alleviate $\mathrm{Al}$ stress, wheat grains were pretreated with $\mathrm{SO}_{2}$ donor concentrations ranging from 0.4 to $2.0 \mathrm{mM}$ for $12 \mathrm{~h}$ prior to incubation with $15 \mathrm{mM} \mathrm{Al}$ (Table 2 and Figure 1). At all $\mathrm{SO}_{2}$ donor concentrations used, $\mathrm{SO}_{2}$ pretreatment was effective in alleviating the toxic effects of $\mathrm{Al}$ in a dose dependent manner. The optimal $\mathrm{SO}_{2}$ donor concentration for alleviating $\mathrm{Al}$ stress was $1.2 \mathrm{mM}$, a concentration where the germination percentage was increased by $51 \%$, radicle and coleoptile length by $28 \%$ and $26 \%$, respectively, compared with those exposed to Al. This result clearly shows that $\mathrm{SO}_{2}$ alleviates $\mathrm{Al}$-induced inhibition of wheat grain germination and seedling growth.

3.3. Effect of $\mathrm{SO}_{2}$ Donor on the Contents of Reducing Sugars and Soluble Protein in Al-Stressed Wheat Grain. Figure 2(a) shows the changes in reducing sugars in germinating wheat grains preincubated in $\mathrm{SO}_{2}$ donor or $\mathrm{H}_{2} \mathrm{O}$ for $12 \mathrm{~h}$ followed by incubation in $\mathrm{Al}$ for $48 \mathrm{~h}$. Within $12 \mathrm{~h}$ pretreatment in $\mathrm{H}_{2} \mathrm{O}$ and $24 \mathrm{~h}$ of $\mathrm{Al}$ treatment, the content of reducing sugar decreased gradually, whereas reducing sugar in the $\mathrm{SO}_{2}$ donor pretreatment remained stable and slightly increased at $24 \mathrm{~h}$. Thereafter reducing sugar content increased steadily in both treatments followed by a slight decrease at $48 \mathrm{~h}$. The content of reducing sugars in $\mathrm{SO}_{2}$ donor pretreated grain was always significantly higher than the counterpart of only $\mathrm{Al}$ treatment.

The content of soluble protein increased gradually and peaked on $24 \mathrm{~h}$ of $\mathrm{Al}$ stress followed by a slight decrease (Figure 2(b)). Though the mean values of soluble protein in 
TABLE 2: Effects of $\mathrm{SO}_{2}$ donor pretreatment on wheat grain germination under $15 \mathrm{mM} \mathrm{Al}^{3+}$ stress. Wheat grains were pretreated with $0,0.4$, $0.8,1.2,1.6$, and $2.0 \mathrm{mM} \mathrm{SO}_{2}$ for $12 \mathrm{~h}$ and subsequently subjected to $15 \mathrm{mM} \mathrm{AlCl}_{3}$ for further $48 \mathrm{~h}$, and then germination was investigated.

\begin{tabular}{|c|c|c|c|c|c|c|}
\hline $\mathrm{SO}_{2}$ donor concentration $(\mathrm{mM})$ & 0.0 & 0.4 & 0.8 & 1.2 & 1.6 & 2.0 \\
\hline Germination percentage (\%) & $37 \pm 3.3^{\mathrm{a}}$ & $42 \pm 2.7^{\mathrm{a}}$ & $44 \pm 3.5^{\mathrm{a}}$ & $56 \pm 3.8^{\mathrm{a}}$ & $48 \pm 2.7^{\mathrm{a}}$ & $47 \pm 3.1^{\mathrm{a}}$ \\
\hline Length of radicle $(\mathrm{cm})$ & $1.42 \pm 0.6^{\mathrm{a}}$ & $1.72 \pm 0.4^{\mathrm{a}}$ & $1.80 \pm 0.7^{\mathrm{a}}$ & $1.82 \pm 0.7^{\mathrm{a}}$ & $1.78 \pm 0.8^{\mathrm{a}}$ & $1.62 \pm 0.4^{\mathrm{a}}$ \\
\hline Length of coleoptile $(\mathrm{cm})$ & $4.64 \pm 0.4^{\mathrm{a}}$ & $4.70 \pm 0.6^{\mathrm{a}}$ & $5.20 \pm 0.5^{\mathrm{a}}$ & $5.83 \pm 0.8^{\mathrm{a}}$ & $5.40 \pm 0.8$ & $5.23 \pm 0.6^{\mathrm{a}}$ \\
\hline Radicle number (50 grains) & $127 \pm 7.3^{\mathrm{a}}$ & $135 \pm 8.1^{\mathrm{a}}$ & $139 \pm 8.1^{\mathrm{a}}$ & $148 \pm 7.9^{\mathrm{a}}$ & $130 \pm 6.7^{\mathrm{a}}$ & $119 \pm 7.1^{\mathrm{a}}$ \\
\hline
\end{tabular}

Values are the means $\pm \mathrm{SD}(n=6)$. Different letters mean significance of difference between different treatments $(P<0.05)$.

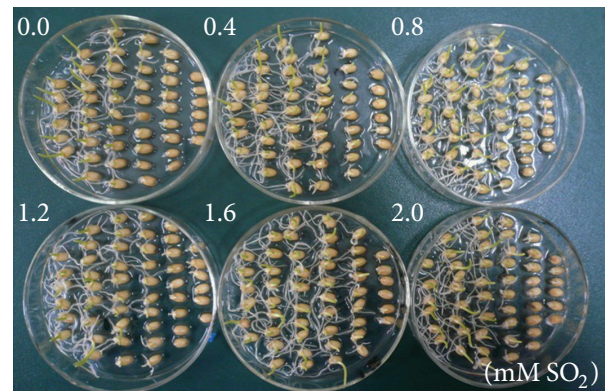

FIGURE 1: Effects of $\mathrm{SO}_{2}$ pretreatment on wheat grain germination under $15 \mathrm{mM} \mathrm{Al}$ stress. Wheat grains were pretreated with $0,0.4,0.8$, $1.2,1.6$, and $2.0 \mathrm{mM} \mathrm{SO}_{2}$ for $12 \mathrm{~h}$, subsequently subjected to $15 \mathrm{mM}$ $\mathrm{Al}$ for further $48 \mathrm{~h}$, and then photographed.

$\mathrm{SO}_{2}$ donor pretreatment were higher than those pretreated in $\mathrm{H}_{2} \mathrm{O}$, they are not significantly different.

\subsection{Effect of $\mathrm{SO}_{2}$ Donor Pretreatment on Contents of Endoge-} nous $\mathrm{H}_{2} \mathrm{~S}, \mathrm{O}_{2}{ }^{\bullet-}, \mathrm{H}_{2} \mathrm{O}_{2}$, and $\mathrm{MDA}$. $\mathrm{H}_{2} \mathrm{~S}$, which can be produced from sulfite, is involved in plant growth regulation including various abiotic stresses $[8,22]$. To investigate whether exogenous $\mathrm{SO}_{2}$ application can induce endogenous $\mathrm{H}_{2} \mathrm{~S}$ production, we measured the concentration of $\mathrm{H}_{2} \mathrm{~S}$ in $\mathrm{Al}$-stressed wheat grain. Generally, $\mathrm{H}_{2} \mathrm{~S}$ accumulated during wheat grain germination following pretreatment with water or $\mathrm{SO}_{2}$, but $\mathrm{SO}_{2}$ donor pretreatment significantly enhanced $\mathrm{H}_{2} \mathrm{~S}$ concentration at $12 \mathrm{~h}$ of pretreatment and $12 \mathrm{~h}, 36 \mathrm{~h}$ of $\mathrm{Al}$ stress (Figure 3(a)).

To study the protective role of $\mathrm{SO}_{2}$ in the Al-stressed wheat grain, reactive oxygen species $\mathrm{O}_{2}{ }^{\cdot-}, \mathrm{H}_{2} \mathrm{O}_{2}$, and malondialdehyde (MDA) were determined with time. As shown in Figure 3(b), a rapid accumulation of $\mathrm{O}_{2}{ }^{--}$was observed when $\mathrm{H}_{2} \mathrm{O}$-pretreated grains were exposed to Al. During the first $12 \mathrm{~h}$ of $\mathrm{Al}$ exposure, the increase in $\mathrm{O}_{2}{ }^{--}$content was very rapid, but this was followed by a slow decrease. In contrast, the content of $\mathrm{O}_{2}{ }^{--}$in $\mathrm{SO}_{2}$ pretreatment increased slowly till $36 \mathrm{~h}$ of $\mathrm{Al}$ stress followed by a decrease. $\mathrm{SO}_{2}$ pretreatment maintained significantly lower level of $\mathrm{O}_{2}{ }^{--}$in Al-stressed wheat grains compared with grains incubated in $\mathrm{H}_{2} \mathrm{O}$ and exposed to $\mathrm{Al}$.

$\mathrm{H}_{2} \mathrm{O}_{2}$ in both treatments increased gradually during pretreatment time and $36 \mathrm{~h}$ of $\mathrm{Al}$ stress and decreased at $48 \mathrm{~h}$ (Figure 3(c)). However, $\mathrm{H}_{2} \mathrm{O}_{2}$ content in $\mathrm{SO}_{2}$ pretreatment was significantly lower than that in water pretreatment when exposed to Al stress.
During the $12 \mathrm{~h}$ pretreatment time, no significant difference was observed in MDA content in wheat grains whether pretreated with $\mathrm{SO}_{2}$ donor or $\mathrm{H}_{2} \mathrm{O}$ (Figure 3(d)). After exposure to $\mathrm{Al}$, the content of MDA in water pretreated grains increased rapidly till $48 \mathrm{~h}$ of $\mathrm{Al}$ stress. An increase of MDA content was also observed in $\mathrm{SO}_{2}$ pretreatment at $12 \mathrm{~h}$ of Al stress, but thereafter MDA content remained stable until $36 \mathrm{~h}$. $\mathrm{SO}_{2}$ pretreatment dramatically reduced the amount of MDA from $24 \mathrm{~h}$ to $48 \mathrm{~h}$ of $\mathrm{Al}$ stress in comparison with grains pretreated in water.

3.5. Effects of $\mathrm{SO}_{2}$ Donor Pretreatment on POD, CAT, APX, and LOX Activities. Activities of POD, CAT, APX, and LOX were determined with time in $\mathrm{SO}_{2}$ donor and $\mathrm{H}_{2} \mathrm{O}$ pretreated grains exposed to $\mathrm{Al}$ (Figure 4). Figure 4(a) shows the time course of POD activity following pretreatment in $\mathrm{SO}_{2}$ donor or $\mathrm{H}_{2} \mathrm{O}$ for $12 \mathrm{~h}$ when POD activity showed almost a twofold increase. During Al stress, POD activity exhibited a gradual increase in both treatments, but $\mathrm{SO}_{2}$ pretreatment maintained significantly higher level of POD activity during Al stress.

The activity of CAT increased almost twofold during $12 \mathrm{~h}$ pretreatment with $\mathrm{H}_{2} \mathrm{O}$ or $\mathrm{SO}_{2}$ donor (Figure 4(b)). After exposure to $\mathrm{Al}, \mathrm{CAT}$ activity in water pretreatment decreased gradually till $48 \mathrm{~h}$ of $\mathrm{Al}$ stress, suggesting that CAT activity is very sensitive to $\mathrm{Al}$ stress. In contrast, CAT activity in $\mathrm{SO}_{2}$ pretreatment increased steadily and decreased only slightly at $48 \mathrm{~h}$ of Al stress.

As shown in Figure 4(c), $\mathrm{SO}_{2}$ pretreatment enhanced APX activity in Al-stressed wheat grain. A rapid increase in APX activity occurred during the pretreatment time in $\mathrm{H}_{2} \mathrm{O}$ and $\mathrm{SO}_{2}$. Within the first $12 \mathrm{~h}$ of $\mathrm{Al}$ stress, APX activity in $\mathrm{H}_{2} \mathrm{O}$-pretreated grains decreased sharply, whereas $\mathrm{SO}_{2}$ donor pretreatment enhanced APX activity slightly. Thereafter APX activity increased steadily in water pretreated grain, whereas its activity in $\mathrm{SO}_{2}$ donor pretreatment fluctuated slightly. The APX activity in $\mathrm{SO}_{2}$ donor pretreated grains was always significantly higher than the counterpart of water pretreatment.

An increase in LOX activity was observed during the first $24 \mathrm{~h}$ of $\mathrm{Al}$ stress in $\mathrm{SO}_{2}$ and $\mathrm{H}_{2} \mathrm{O}$-pretreated grains (Figure $4(\mathrm{~d})$ ). However, the increase of LOX activity in water pretreatment was more rapid than after $\mathrm{SO}_{2}$ pretreatment. Thereafter LOX activity in water pretreatment showed a sharp decrease at $36 \mathrm{~h}$ of $\mathrm{Al}$ stress, while its activity in $\mathrm{SO}_{2}$ pretreatment decreased at $48 \mathrm{~h}$. At 12 and $24 \mathrm{~h}$ of Al stress, $\mathrm{SO}_{2}$ pretreatment maintained significantly lower level of 


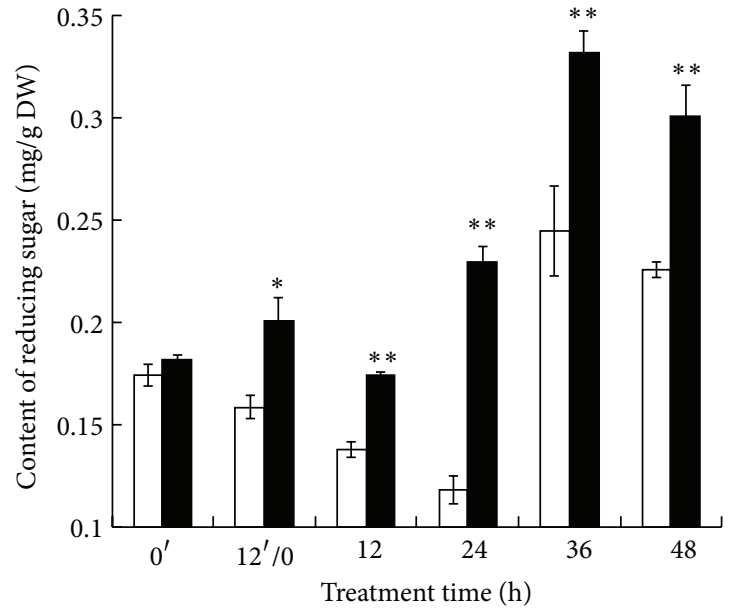

$$
\begin{aligned}
& \square \mathrm{Al} \\
& \square \mathrm{S}+\mathrm{Al}
\end{aligned}
$$

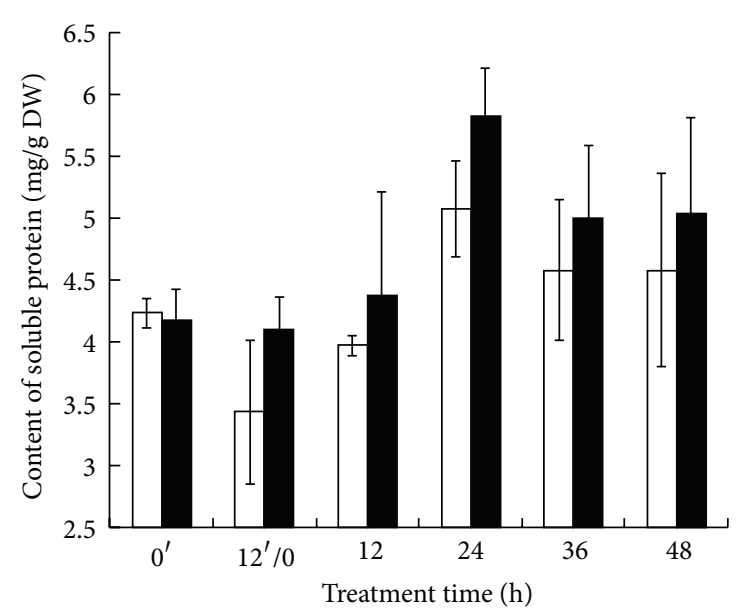

$\square \mathrm{Al}$

- $\mathrm{S}+\mathrm{Al}$

(a)

(b)

FIGURE 2: Effect of $\mathrm{SO}_{2}$ pretreatment on the contents of reducing sugar and soluble protein in Al-treated grain as shown in (a) and (b), respectively. Wheat grains were pretreated with water $(\mathrm{Al})$ or $1.2 \mathrm{mM} \mathrm{SO}_{2}$ donor $(\mathrm{S}+\mathrm{Al})$ for $12 \mathrm{~h}$ (shown from $0^{\prime}$ to $12^{\prime} / 0 \mathrm{~h}$ of pretreatment time) and then exposed to $15 \mathrm{mM} \mathrm{Al}$ for further $48 \mathrm{~h}$ (shown as $12^{\prime} / 0,12,24,36$, and $48 \mathrm{~h}$ ). The symbols $*$ and $* *$ in this figure and following ones stand for significant difference between Al-treated grains with and without $\mathrm{SO}_{2}$ pretreatment at $P<0.05$ and $P<0.01$, respectively.

LOX, while at $36 \mathrm{~h}$ LOX activity in $\mathrm{SO}_{2}$ pretreatment was higher than that of water pretreatment.

3.6. Effects of $\mathrm{SO}_{2}$ Donor Pretreatment on Localization of $\mathrm{Al}$, Lipid Peroxidation, and ROS Production. To detect ROS production in the radicle tips, we used DCFH-DA fluorescence to indicate ROS accumulation. As shown in Figure 5(a), Al treatment induced higher level of ROS in radicle as intense DCFH-DA fluorescence, while $\mathrm{SO}_{2}$ donor pretreatment for $12 \mathrm{~h}$ followed by $\mathrm{Al}$ stress significantly reduced fluorescence. Figure 5(b) shows DCFH-DA fluorescence in maturation zone in radicles. Similarly, intense fluorescence in $\mathrm{SO}_{2}$ donor pretreatment followed by $\mathrm{Al}$ stress was much weaker than that in water pretreated plus Al-stressed radicles, suggesting that $\mathrm{SO}_{2}$ donor was effective in alleviating oxidative stress in radicles. $\mathrm{SO}_{2}$ donor treatment alone showed comparable fluorescence intensity as observed in water control.

The radicles were stained with Evans blue to show membrane integrity. The radicles treated with $\mathrm{Al}$ alone were stained extensively with Evans blue, while Al-stressed radicles pretreated with $\mathrm{SO}_{2}$ donor for $12 \mathrm{~h}$ were less stained (Figure 5(c)), suggesting $\mathrm{SO}_{2}$ donor serves to protect cell membrane from $\mathrm{Al}$-induced damage. $\mathrm{SO}_{2}$ donor treatment alone showed similar Evans blue staining to water control, suggesting no visible damaging effect of $\mathrm{SO}_{2}$ on radicles.

The hematoxylin staining was used to detect $\mathrm{Al}$ accumulation in radicles. As shown in Figure 5(d), the radicles of water control and $\mathrm{SO}_{2}$ treatment incubated with hematoxylin showed no dark staining but wheat radicles treated with $\mathrm{Al}$ alone were stained intensively. In contrast, radicles pretreated with $\mathrm{SO}_{2}$ donor for $12 \mathrm{~h}$ and then exposed to $\mathrm{Al}$ for $48 \mathrm{~h}$ showed much weaker staining compared with Al stress, especially in the elongation zone.

3.7. Effect of $\mathrm{SO}_{2}$ Donor Pretreatment on the Relative Expressions of Aluminum Stress Related Genes. We determined the changes in gene expression of aluminum stress related genes in wheat radicles. Radicles were pretreated with or without $1 \mathrm{mM} \mathrm{SO}_{2}$ donors for $12 \mathrm{~h}$ and then exposed to $\mathrm{Al}$ for $48 \mathrm{~h}$. As shown in Figure 6, Al stress induced higher expression of TaWalil, TaWali2, TaWali3, TaWali5, and TaWali6 (wheat aluminum induced) in radicles, while pretreatment with $\mathrm{SO}_{2}$ donor for $12 \mathrm{~h}$ followed by $\mathrm{Al}$ stress alleviated such expression increase. Besides, the gene expression of TaALMT1 (Alactivated malate transporter) was also attenuated by $\mathrm{SO}_{2}$ pretreatment.

\section{Discussion}

In solution, $\mathrm{SO}_{2}$ is dissociated from its sulfite derivatives $\left(\mathrm{NaHSO}_{3} / \mathrm{Na}_{2} \mathrm{SO}_{3}\right.$ 1:3 M/M) [34]. Thus $\mathrm{NaHSO}_{3} / \mathrm{Na}_{2} \mathrm{SO}_{3}$ $(1: 3 \mathrm{M} / \mathrm{M})$ was chosen as an $\mathrm{SO}_{2}$ donor in our study. Similar to the observation that $\mathrm{H}_{2} \mathrm{~S}$ could promote wheat grain germination and alleviate oxidative damage against $\mathrm{Al}$ stress [8], our results show that $\mathrm{SO}_{2}$ donor pretreatment alleviates $\mathrm{Al}$ stress in germinating wheat seedlings. Wheat grains pretreated for $12 \mathrm{~h}$ with the $\mathrm{SO}_{2}$ donor show an increase in germination percentage, coleoptile length, radicle length, and radicle numbers of wheat. The increase in the contents of reducing sugars and soluble protein suggests that nutrients in wheat grains pretreated with $\mathrm{SO}_{2}$ donor are rapidly mobilized to provide energy to grain germination. $\mathrm{SO}_{2}$ donor maintained lower level of $\mathrm{H}_{2} \mathrm{O}_{2}, \mathrm{O}_{2}{ }^{--}$, and MDA probably 


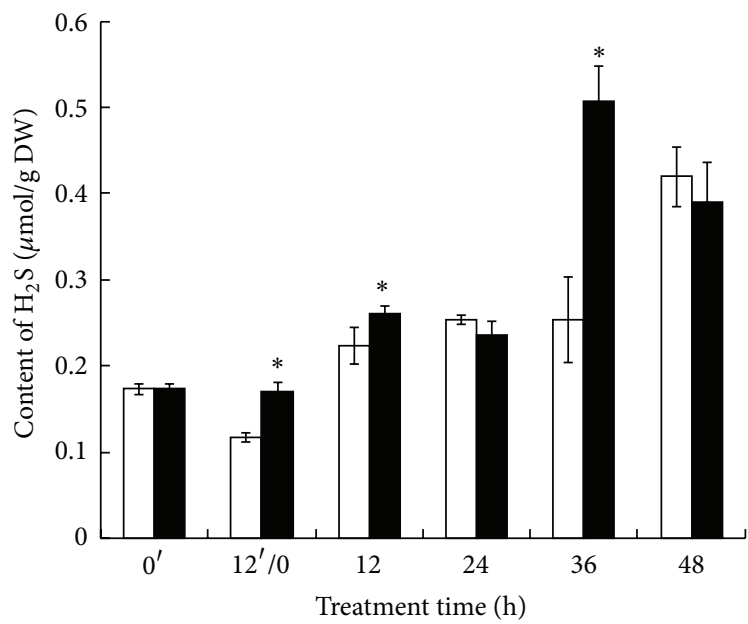

$$
\begin{aligned}
& \square \mathrm{Al} \\
& \square \mathrm{S}+\mathrm{Al}
\end{aligned}
$$

(a)

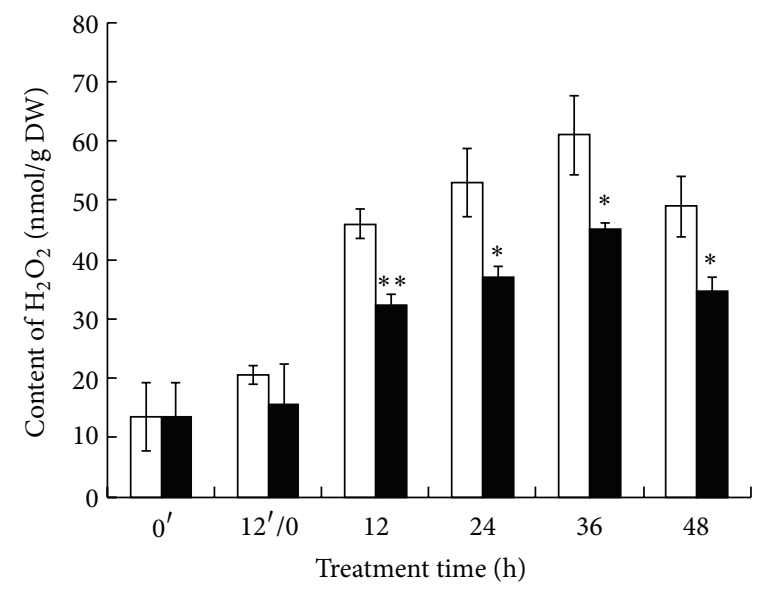

$$
\begin{aligned}
& \square \mathrm{Al} \\
& \mathrm{S}+\mathrm{Al}
\end{aligned}
$$

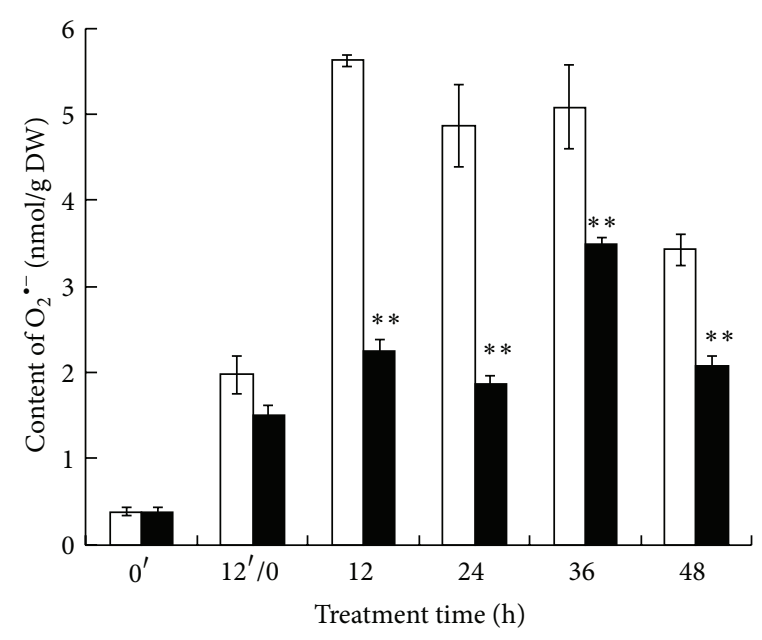

$\square \mathrm{Al}$

- $\mathrm{S}+\mathrm{Al}$

(b)

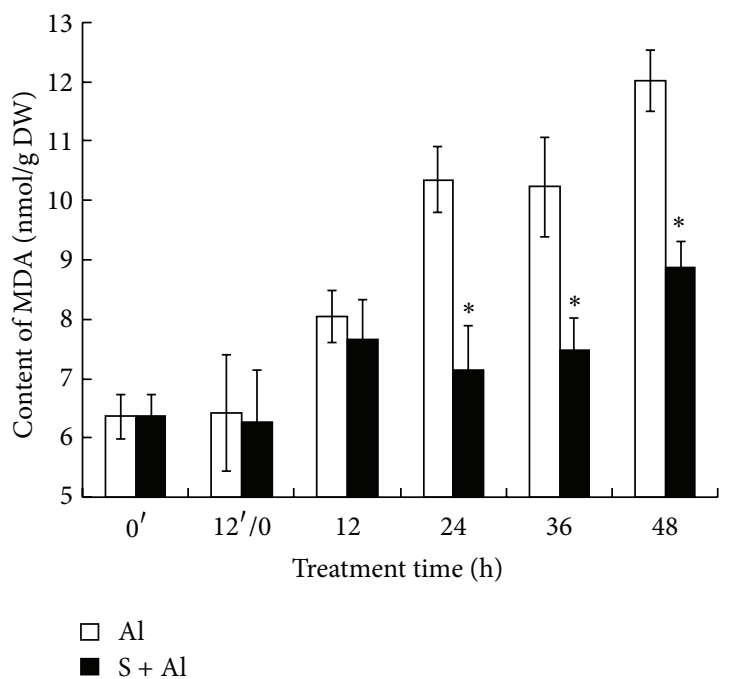

(d)

FIGURE 3: Effects of $\mathrm{SO}_{2}$ pretreatment on the accumulation of endogenous $\mathrm{H}_{2} \mathrm{~S}(\mathrm{a})$, superoxide anion $\left(\mathrm{O}_{2}{ }^{--}\right)(\mathrm{b})$, hydrogen peroxide $\left(\mathrm{H}_{2} \mathrm{O}_{2}\right)$ (c), and malondialdehyde (MDA) (d) in germinating wheat grains under $\mathrm{Al}$ stress. The numbers $\left(0^{\prime}, 12^{\prime} / 0,12,24,36\right.$, and 48$)$ or letters $(\mathrm{CK}$ or $\mathrm{SO}_{2}$ ) presented are the same as mentioned in Figure 2. $\mathrm{Al}$ : $\mathrm{Al}$ stress without $\mathrm{SO}_{2}$ pretreatment; $\mathrm{S}+\mathrm{Al}$ : $\mathrm{Al}$ stress with $\mathrm{SO}_{2}$ pretreatment.

by activation of the antioxidant system. These results suggest that $\mathrm{SO}_{2}$ acts as an antioxidant and may function in a way that is similar to what the effects of $\mathrm{H}_{2} \mathrm{~S}, \mathrm{CO}$, and $\mathrm{NO}$ do in plants exposed to heavy metal stress $[10,35]$.

Sulfite can be reduced by sulfite reductase to $\mathrm{H}_{2} \mathrm{~S}$, which is incorporated into $\mathrm{O}$-acetylserine via $\mathrm{O}$-acetyl(thiol)lyase to form cysteine [22]. In RNA interfered mutant of sulfite reductase (SiR), sulfide synthesis in younger leaves was decreased by the impaired $\mathrm{SiR}$ activity [36]. In the present study, exogenous $\mathrm{SO}_{2}$ application can induce endogenous $\mathrm{H}_{2} \mathrm{~S}$ production in Al-stressed wheat grains (Figure 3(a)), suggesting the interplay between sulfite and the formation of $\mathrm{H}_{2} \mathrm{~S}$.

Consistent with previous observations [7], our results show that $\mathrm{Al}$ stress caused overproduction of ROS in wheat.
To mitigate and repair oxidative damage, plants have evolved an efficient antioxidant system that includes enzymes such as SOD, CAT, and APX that function to scavenge ROS [37]. SOD catalyzes the dismutation of the superoxide radical $\mathrm{O}_{2}{ }^{\circ-}$ and $\mathrm{H}^{+}$into $\mathrm{H}_{2} \mathrm{O}_{2}$. CAT, APX, and POD are responsible for the elimination of $\mathrm{H}_{2} \mathrm{O}_{2}$ generated by SOD. $\mathrm{Al}$ stress brings about a dramatic increase in $\mathrm{H}_{2} \mathrm{O}_{2}$ and $\mathrm{O}_{2}{ }^{--}$. The elevated levels of $\mathrm{H}_{2} \mathrm{O}_{2}$ and $\mathrm{O}_{2}{ }^{-}$suggest that antioxidant enzymes in Alstressed wheat do not efficiently scavenge the overproduction of ROS, and this can result in lipid peroxidation or plasma membrane inhibiting grain germination and seedling growth [8]. Our data show that pretreatment of wheat with $\mathrm{SO}_{2}$ donor activates antioxidant enzymes including POD, CAT, and APX. 

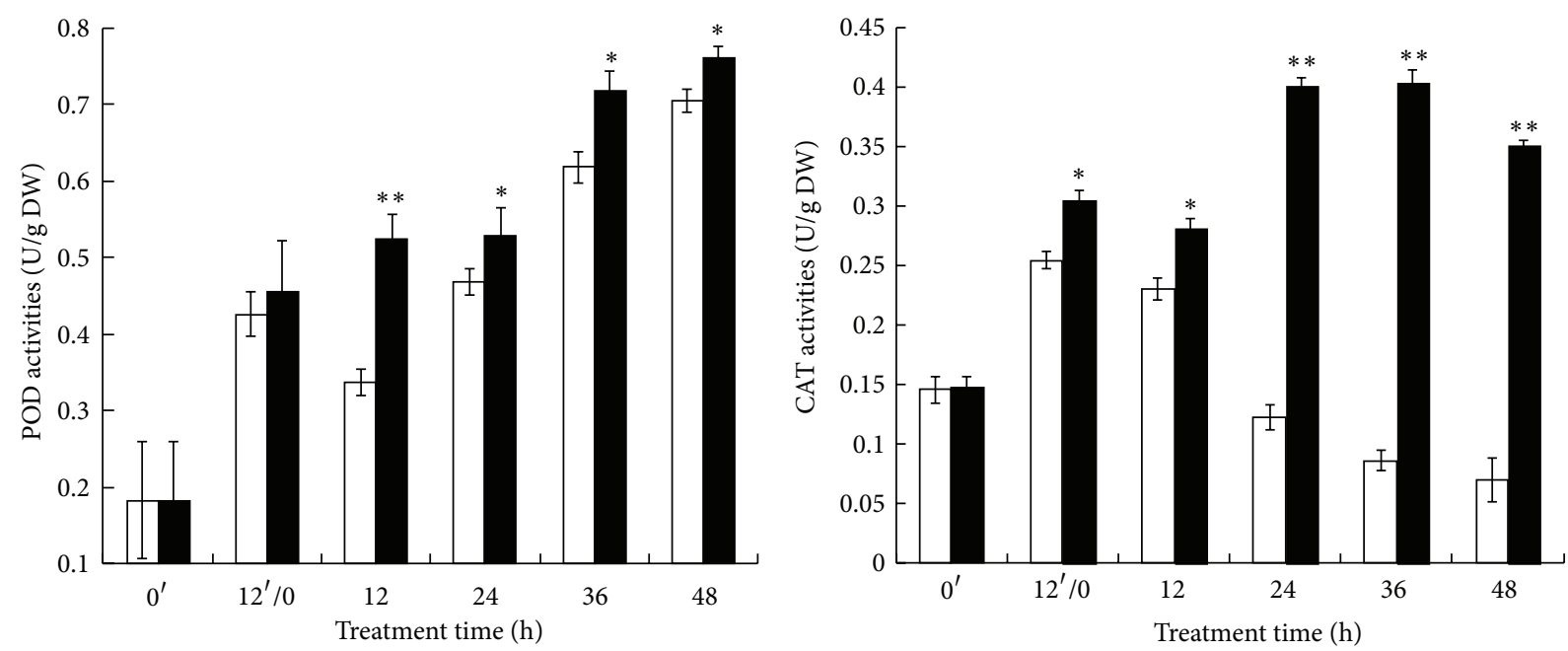

$\square \mathrm{Al}$

$\square \mathrm{S}+\mathrm{Al}$

(a)

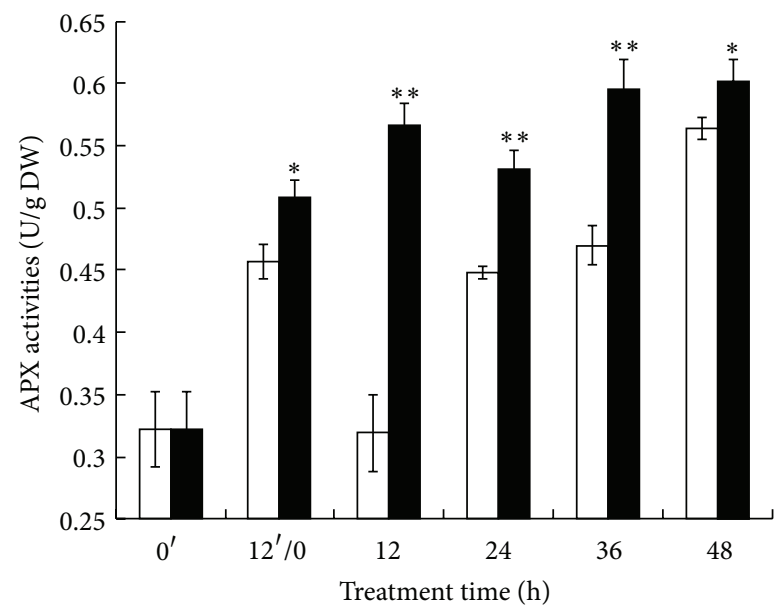

$\square \mathrm{Al}$

- $\mathrm{S}+\mathrm{Al}$ $\square \mathrm{Al}$

$\square \mathrm{S}+\mathrm{Al}$

(b)

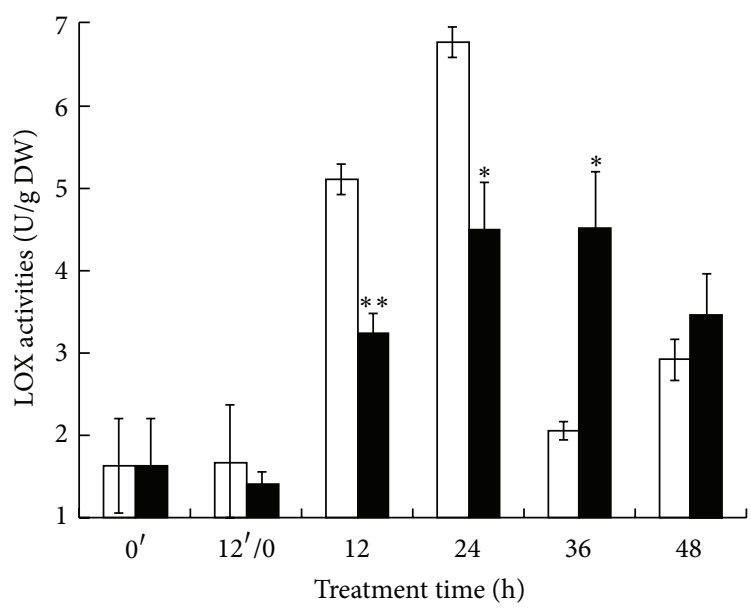

$\square \mathrm{Al}$

- $\mathrm{S}+\mathrm{Al}$

(c)

(d)

Figure 4: Effect of $\mathrm{SO}_{2}$ donor pretreatment on the activities of POD (a), CAT (b), APX (c), and LOX (d) in germinating wheat grains under $15 \mathrm{mM} \mathrm{Al}$ stress. Grains were treated and the number or letters presented are the same as mentioned in Figure 2. $\mathrm{Al}$ : $\mathrm{Al}$ stress without $\mathrm{SO}_{2}$ pretreatment; $\mathrm{S}+\mathrm{Al}$ : $\mathrm{Al}$ stress with $\mathrm{SO}_{2}$ pretreatment.

LOX, which catalyzes oxygenation of polyunsaturated fatty acids into lipid hydroperoxides, is considered an indicator of oxidative stress during responses to various environmental stresses [9]. Pretreatment with $\mathrm{SO}_{2}$ donor lowers LOX activity in Al-stressed wheat radicles compared to seedlings pretreated with $\mathrm{H}_{2} \mathrm{O}$ and exposed to Al. The lowering of LOX by $\mathrm{SO}_{2}$ pretreatment also helps to explain the lower MDA content of Al-stressed grain. Taken together, these data suggest that $\mathrm{SO}_{2}$ donor reduced oxidative stress by modulation of the antioxidant system.

Our data indicate that the radicle is the primary target for Al toxicity. DCFH-DA fluorescence assay shows that $\mathrm{Al}$ incubation induces higher accumulation of ROS in radicle tips and maturation zone. $\mathrm{SO}_{2}$ donor pretreatment effectively reduces $\mathrm{ROS}$ content in subsequent $\mathrm{Al}$ stress, suggesting the role of $\mathrm{SO}_{2}$ in alleviating oxidative stress. Correspondently, $\mathrm{Al}$ stress causes membrane injury to radicles, while $\mathrm{SO}_{2}$ donor effectively alleviates such injury. To understand whether $\mathrm{SO}_{2}$ donor helps to reduce $\mathrm{Al}$ accumulation in radicles, hematoxylin staining was used to indicate $\mathrm{Al}$ and the results show that $\mathrm{SO}_{2}$ donor obviously reduces $\mathrm{Al}$ content in radicles, implying a potential role of $\mathrm{SO}_{2}$ donor treatment as a strategy to reduce Al uptake.

In response to $\mathrm{Al}$ stress, many gene expressions are activated, for instance, TaWali (wheat aluminum induced), aluminum-activated malate transporter (TaALMT1) [38-41]. 

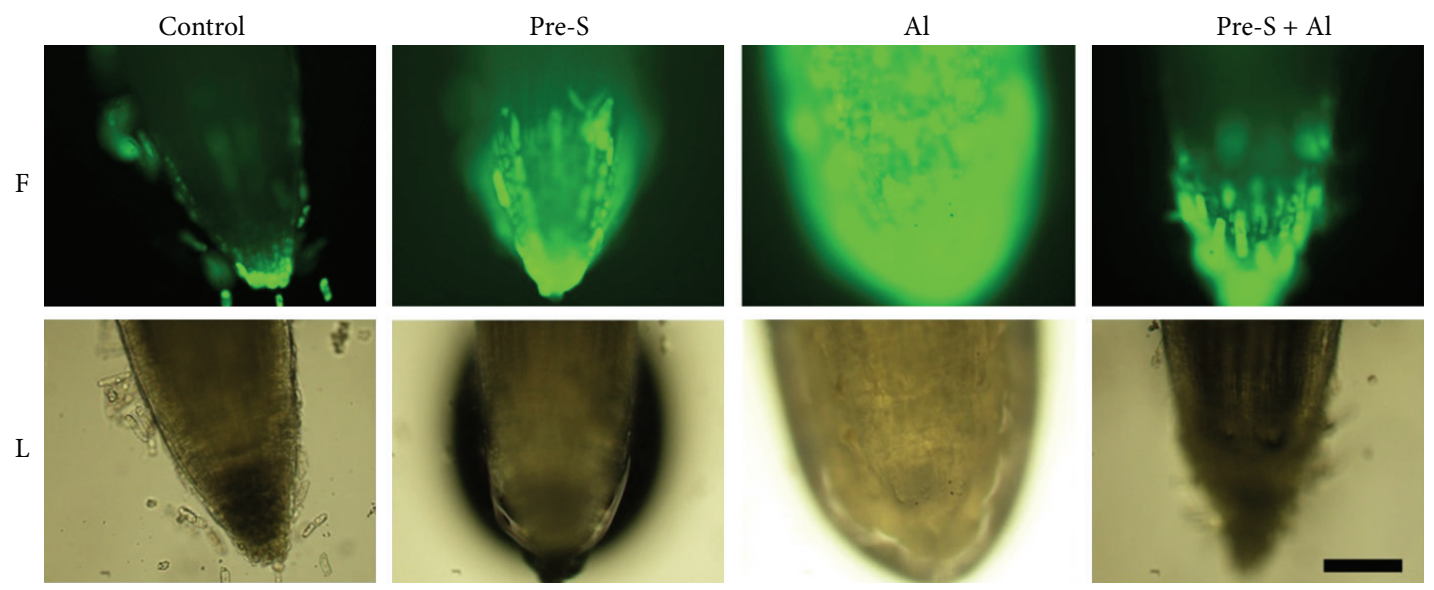

(a)
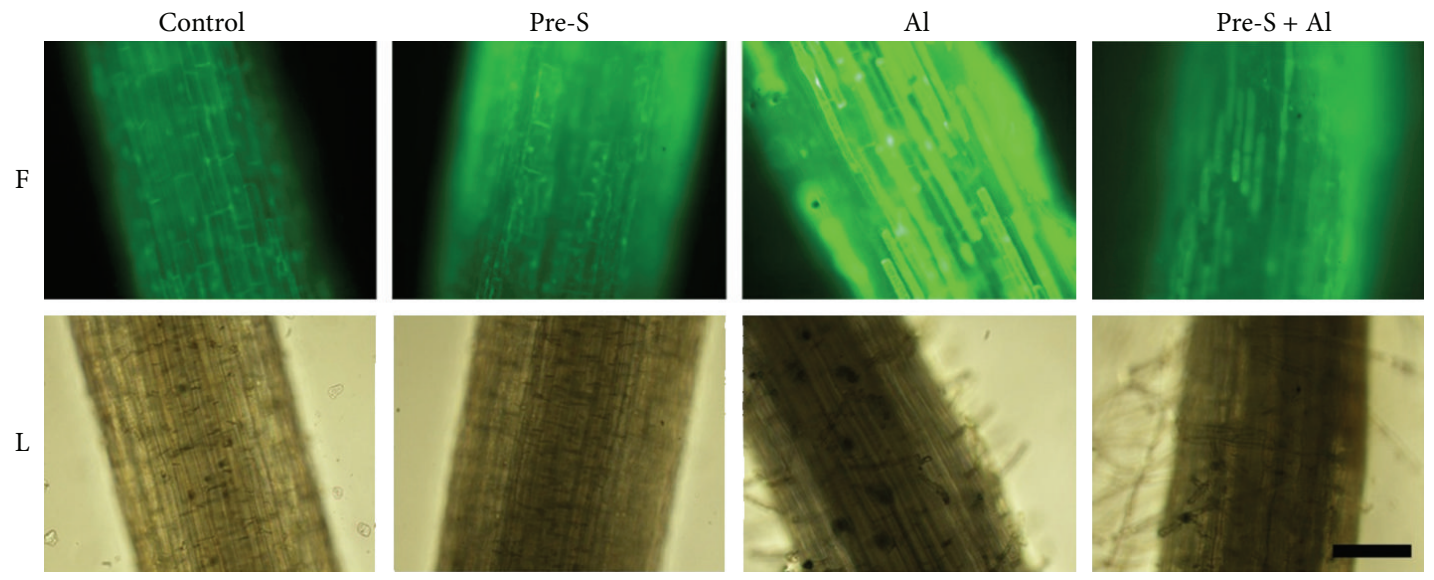

(b)

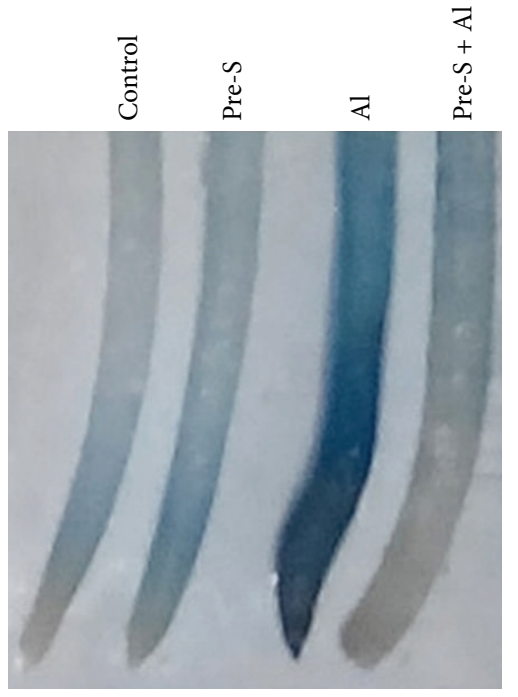

Evans blue staining

(c)

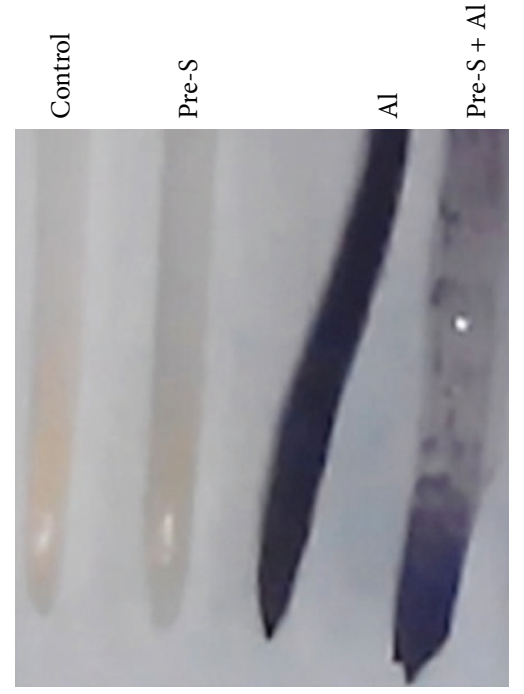

Hematoxylin staining

(d)

FIGURE 5: ROS staining ((a) on radicle tips; (b) on maturation zone; bar: $200 \mu \mathrm{m})$, Evans blue staining (c), and hematoxylin staining (d) in wheat radicles. Initially, wheat grains were geminated in water for $36 \mathrm{~h}$. Then four treatment groups were done as follows, control, $60 \mathrm{~h}$ in $\mathrm{H}_{2} \mathrm{O}$; Pre-S, pretreatment with $1 \mathrm{mM} \mathrm{SO}_{2}$ donor for $12 \mathrm{~h}$, and then exposed to $\mathrm{H}_{2} \mathrm{O}$ for $48 \mathrm{~h} ; \mathrm{Al}, 12 \mathrm{~h}$ in $\mathrm{H}_{2} \mathrm{O}$ prior to exposure to $400 \mu \mathrm{M}$ $\mathrm{AlCl}_{3}$ for $48 \mathrm{~h}$; Pre-S $+\mathrm{Al}, 12 \mathrm{~h}$ in $1 \mathrm{mM} \mathrm{SO}_{2}$ donor pretreatment followed by $400 \mu \mathrm{M} \mathrm{AlCl}_{3}$ for $48 \mathrm{~h}$. 

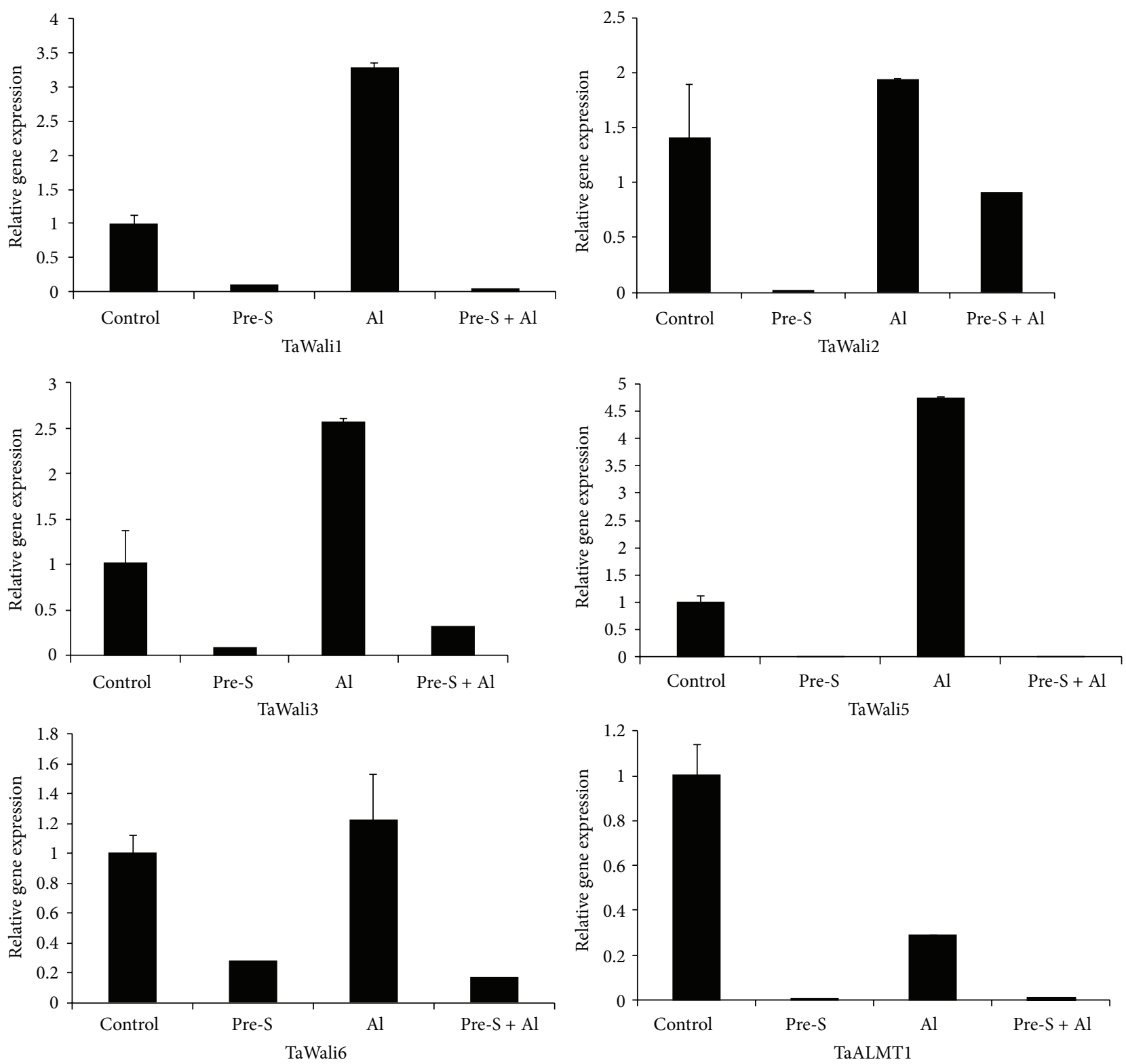

FIGURE 6: Effect of $\mathrm{SO}_{2}$ donor pretreatment on relative gene expression of TaWali1, TaWali2, TaWali3, TaWali5, TaWali6, and TaALMT1 in wheat radicals exposed to $\mathrm{Al}$ stress. Initially, wheat grains were geminated in water for $36 \mathrm{~h}$. Then four treatment groups were done as follows, control, $60 \mathrm{~h}$ in $\mathrm{H}_{2} \mathrm{O}$; Pre-S, pretreatment with $1 \mathrm{mM} \mathrm{SO}_{2}$ donor for $12 \mathrm{~h}$, and then exposed to $\mathrm{H}_{2} \mathrm{O}$ for $48 \mathrm{~h} ; \mathrm{Al}, 12 \mathrm{~h}$ in $\mathrm{H}_{2} \mathrm{O}$ prior to exposure to $400 \mu \mathrm{M} \mathrm{AlCl}_{3}$ for $48 \mathrm{~h}$; Pre-S $+\mathrm{Al}, 12 \mathrm{~h}$ in $1 \mathrm{mM} \mathrm{SO}_{2}$ donor pretreatment followed by $400 \mu \mathrm{M} \mathrm{AlCl}_{3}$ for $48 \mathrm{~h}$.

Relative gene expression analysis shows that $\mathrm{Al}$ treatment induces higher expression of TaWali, while these gene expression levels are reduced by $\mathrm{SO}_{2}$ donor pretreatment, suggesting the response to $\mathrm{Al}$ stress is attenuated in $\mathrm{SO}_{2}$ donor pretreatment.

\section{Conclusion}

In the present study, $\mathrm{SO}_{2}$ acts as an antioxidant signal to reduce ROS damage in wheat grains and radicles caused by $\mathrm{Al}$ stress. Besides, $\mathrm{SO}_{2}$ also decreases $\mathrm{Al}$ uptake. The induced higher level of $\mathrm{H}_{2} \mathrm{~S}$ suggests an intricate interplay of $\mathrm{SO}_{2}$ and $\mathrm{H}_{2} \mathrm{~S}$ in plants. Exogenous application of $\mathrm{SO}_{2}$ may be reduced to $\mathrm{H}_{2} \mathrm{~S}$ by sulfite reductase, thus contributing to $\mathrm{H}_{2} \mathrm{~S}$ production. $\mathrm{H}_{2} \mathrm{~S}$ in itself acts as an antioxidant signaling molecule in plants' response to abiotic stress. Thus the nature of $\mathrm{SO}_{2}$ /sulfite functions in alleviating $\mathrm{Al}$ stress still needs further research.

\section{Conflict of Interests}

The authors declare that there is no conflict of interests regarding the publication of this paper. 


\section{Authors' Contribution}

Dong-Bo Zhu, Kang-Di Hu, and Xi-Kai Guo contributed equally to this work.

\section{Acknowledgments}

This work was supported by the Natural Science Foundation of China (31271803, 31301820, 31300133, and 31470013), the Scientific Research Foundation for Returned Overseas Chinese Scholars (SRF for ROCS, MOE), the Natural Science Foundations of Anhui Province (11040606M85), and the Anhui Provincial Education Department (2012AJZR0028, ZD200910).

\section{References}

[1] P. R. Ryan, S. D. Tyerman, T. Sasaki et al., "The identification of aluminium-resistance genes provides opportunities for enhancing crop production on acid soils," Journal of Experimental Botany, vol. 62, no. 1, pp. 9-20, 2011.

[2] Z. Q. Wang, X. Y. Xu, Q. Q. Gong et al., "Root proteome of rice studied by iTRAQ provides integrated insight into aluminum stress tolerance mechanisms in plants," Journal of Proteomics, vol. 98, no. 26, pp. 189-205, 2014.

[3] W. Huang, X. Yang, S. Yao et al., "Reactive oxygen species burst induced by aluminum stress triggers mitochondria-dependent programmed cell death in peanut root tip cells," Plant Physiology and Biochemistry, vol. 82, no. 12, pp. 76-84, 2014.

[4] Y.-S. Wang and Z.-M. Yang, "Nitric oxide reduces aluminum toxicity by preventing oxidative stress in the roots of Cassia tora L," Plant and Cell Physiology, vol. 46, no. 12, pp. 1915-1923, 2005.

[5] K. Tahara, T. Yamanoshita, M. Norisada et al., "Aluminum distribution and reactive oxygen species accumulation in root tips of two Melaleuca trees differing in aluminum resistance," Plant and Soil, vol. 307, no. 1-2, pp. 167-178, 2008.

[6] Z. J. Ding, J. Y. Yan, X. Y. Xu, G. X. Li, and S. J. Zheng, "WRKY46 functions as a transcriptional repressor of ALMT1, regulating aluminum-induced malate secretion in Arabidopsis," The Plant Journal, vol. 76, no. 5, pp. 825-835, 2013.

[7] S. J. Zheng and J. L. Yang, "Target sites of aluminum phytotoxicity," Biologia Plantarum, vol. 49, no. 3, pp. 321-331, 2005.

[8] H. Zhang, Y. H. Li, L. Y. Hu, S. H. Wang, F. Q. Zhang, and K. D. Hu, "Effects of exogenous nitric oxide donor on antioxidant metabolism in wheat leaves under aluminum stress," Russian Journal of Plant Physiology, vol. 55, no. 4, pp. 469-474, 2008.

[9] H. Zhang, Z.-Q. Tan, L.-Y. Hu, S.-H. Wang, J.-P. Luo, and R. L. Jones, "Hydrogen sulfide alleviates aluminum toxicity in germinating wheat seedlings," Journal of Integrative Plant Biology, vol. 52, no. 6, pp. 556-567, 2010.

[10] J. Xu, W. Xuan, B. Huang et al., "Carbon monoxide-induced adventitious rooting of hypocotyl cuttings from mung bean seedling," Chinese Science Bulletin, vol. 51, no. 6, pp. 668-674, 2006.

[11] S. Q. Zhang, J. B. Du, H. F. Jin et al., "Endogenous sulfur dioxide aggravates myocardial injury in isolated rat heart with ischemia and reperfusion," Transplantation, vol. 87, no. 4, pp. 517-524, 2009.

[12] R. Y. Zhang, J. B. Du, Y. Sun et al., "Sulfur dioxide derivatives depress L-type calcium channel in rat cardiomyocytle," Clinical and Experimental Pharmacology and Physiology, vol. 38, no. 7, pp. 416-422, 2011.

[13] H.-F. Jin, S.-X. Du, X. Zhao et al., "Effects of endogenous sulfur dioxide on monocrotaline-induced pulmonary hypertension in rats," Acta Pharmacologica Sinica, vol. 29, no. 10, pp. 1157-1166, 2008.

[14] I. Ziegler, "The effect of $\mathrm{SO}_{2}$ pollution on plant metabolism," Residue Reviews, vol. 56, no. 1, pp. 79-105, 1975.

[15] R. Sandhu, Y. Li, and G. Gupta, "Sulphur dioxide and carbon dioxide induced changes in soybean physiology," Plant Science, vol. 83, no. 1, pp. 31-34, 1992.

[16] D. Yarmolinsky, G. Brychkova, R. Fluhr, and M. Sagi, "Sulfite reductase protects plants against sulfite toxicity," Plant Physiology, vol. 161, no. 2, pp. 725-743, 2013.

[17] M. Noji, M. Saito, M. Nakamura, M. Aono, H. Saji, and K. Saito, "Cysteine synthase overexpression in tobacco confers tolerance to sulfur-containing environmental pollutants," Plant Physiology, vol. 126, no. 3, pp. 973-980, 2001.

[18] R. Rakwal, G. K. Agrawal, A. Kubo et al., "Defense/stress responses elicited in rice seedlings exposed to the gaseous air pollutant sulfur dioxide," Environmental and Experimental Botany, vol. 49, no. 3, pp. 223-235, 2003.

[19] J. J. Yin, X. Liu, H. L. Yi, and M. L. Yang, "Sulfur dioxide induces guard cell death in Vicia faba," Acta Scientiae Circumstantiae, vol. 30 , no. 12 , pp. 2512-2517, 2010.

[20] H. Rennenberg, "The fate of excess sulfur in higher plants," Annual Review of Plant Physiology, vol. 35, no. 4, pp. 121-153, 1984.

[21] E. Giraud, A. Ivanova, C. S. Gordon, J. Whelan, and M. J. Considine, "Sulphur dioxide evokes a large scale reprogramming of the grape berry transcriptome associated with oxidative signalling and biotic defence responses," Plant, Cell and Environment, vol. 35, no. 2, pp. 405-417, 2012.

[22] T. Rausch and A. Wachter, "Sulfur metabolism: a versatile platform for launching defence operations," Trends in Plant Science, vol. 10, no. 10, pp. 503-509, 2005.

[23] M. H. Stipanuk, J. E. Dominy Jr., J.-I. Lee, and R. M. Coloso, "Mammalian cysteine metabolism: new insights into regulation of cysteine metabolism," Journal of Nutrition, vol. 136, no. 6, pp. 1652S-1659S, 2006.

[24] A. Laisk, H. Pfanz, and U. Heber, "Sulfur-dioxide fluxes into different cellular compartments of leaves photosynthesizing in a polluted atmosphere: II. Consequences of $\mathrm{SO}_{2}$ uptake as revealed by computer analysis," Planta, vol. 173, no. 2, pp. 241252,1988

[25] H. Zhang, S.-L. Hu, Z.-J. Zhang et al., "Hydrogen sulfide acts as a regulator of flower senescence in plants," Postharvest Biology and Technology, vol. 60, no. 3, pp. 251-257, 2011.

[26] K. Surrey, "Spectrophotometric method for determination of lipoxidase activity," Plant Physiology, vol. 39, no. 1, pp. 65-70, 1964.

[27] L.-Y. Hu, S.-L. Hu, J. Wu et al., "Hydrogen sulfide prolongs postharvest shelf life of strawberry and plays an antioxidative role in fruits," Journal of Agricultural and Food Chemistry, vol. 60, no. 35, pp. 8684-8693, 2012.

[28] G. L. Miller, "Use of dinitrosalicylic acid reagent for determination of reducing sugar," Analytical Chemistry, vol. 31, no. 3, pp. 426-428, 1959.

[29] M. M. Bradford, "A rapid and sensitive method for the quantitation of microgram quantities of protein utilizing the principle of protein dye binding," Analytical Biochemistry, vol. 72, no. 1-2, pp. 248-254, 1976. 
[30] Y. Yamamoto, Y. Kobayashi, S. R. Devi, S. Rikiishi, and H. Matsumoto, "Aluminum toxicity is associated with mitochondrial dysfunction and the production of reactive oxygen species in plant cells," Plant Physiology, vol. 128, no. 1, pp. 63-72, 2002.

[31] E. Polle, C. F. Konzak, and J. A. Kittrick, "Visual detection of aluminum tolerance levels in wheat by hematoxylin staining of seeding roots," Crop Science, vol. 18, no. 5, pp. 823-827, 1978.

[32] C. P. LeBel, H. Ischiropoulos, and S. C. Bondy, "Evaluation of the probe $2^{\prime}, 7^{\prime}$-dichlorofluorescin as an indicator of reactive oxygen species formation and oxidative stress," Chemical Research in Toxicology, vol. 5, no. 2, pp. 227-231, 1992.

[33] S.-P. Li, K.-D. Hu, L.-Y. Hu et al., "Hydrogen sulfide alleviates postharvest senescence of broccoli by modulating antioxidant defense and senescence-related gene expression," Journal of Agricultural and Food Chemistry, vol. 62, no. 5, pp. 1119-1129, 2014.

[34] R. Shapiro, "Genetic effects of bisulfite (sulfur dioxide)," Mutation Research, vol. 39, no. 2, pp. 149-175, 1977.

[35] K.-D. Hu, L.-Y. Hu, Y.-H. Li, F.-Q. Zhang, and H. Zhang, "Protective roles of nitric oxide on germination and antioxidant metabolism in wheat seeds under copper stress," Plant Growth Regulation, vol. 53, no. 3, pp. 173-183, 2007.

[36] D. Yarmolinsky, G. Brychkova, A. Kurmanbayeva et al., "Impairment in sulfite reductase leads to early leaf senescence in tomato plants," Plant Physiology, vol. 165, no. 4, pp. 1505-1520, 2014.

[37] P. Sharma and R. S. Dubey, "Involvement of oxidative stress and role of antioxidative defense system in growing rice seedlings exposed to toxic concentrations of aluminum," Plant Cell Reports, vol. 26, no. 11, pp. 2027-2038, 2007.

[38] K. C. Snowden and R. C. Gardner, "Five genes induced by aluminum in wheat (Triticum aestivum L.) roots," Plant Physiology, vol. 103, no. 3, pp. 855-861, 1993.

[39] A. Ligaba, I. Dreyer, A. Margaryan, D. J. Schneider, L. Kochian, and M. Piñeros, "Functional, structural and phylogenetic analysis of domains underlying the $\mathrm{Al}$ sensitivity of the aluminumactivated malate/anion transporter, TaALMT1," The Plant Journal, vol. 76, no. 5, pp. 766-780, 2013.

[40] N. Yoshimoto, H. Takahashi, F. W. Smith, T. Yamaya, and K. Saito, "Two distinct high-affinity sulfate transporters with different inducibilities mediate uptake of sulfate in Arabidopsis roots," The Plant Journal, vol. 29, no. 4, pp. 465-473, 2002.

[41] T. Kataoka, A. Watanabe-Takahashi, N. Hayashi et al., "Vacuolar sulfate transporters are essential determinants controlling internal distribution of sulfate in Arabidopsis," The Plant Cell, vol. 16, no. 10, pp. 2693-2704, 2004. 


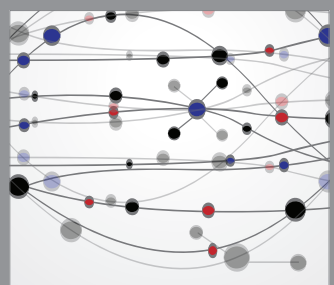

The Scientific World Journal
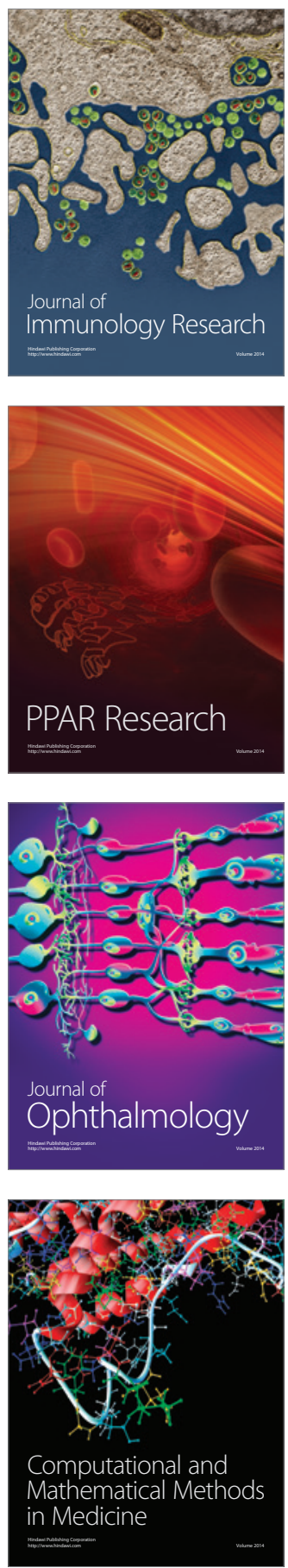

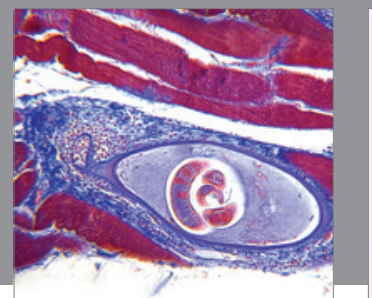

Gastroenterology

Research and Practice
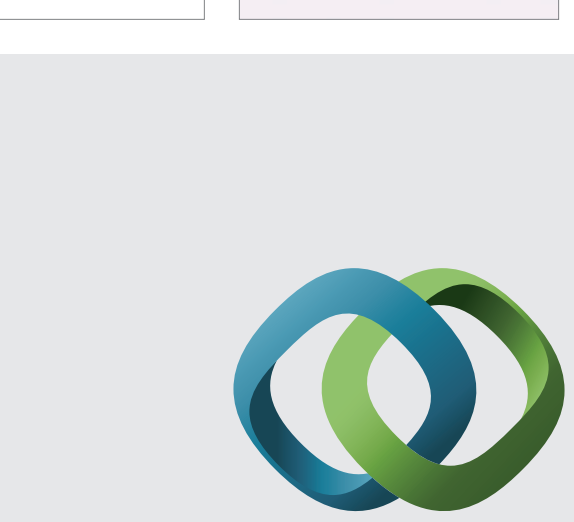

\section{Hindawi}

Submit your manuscripts at

http://www.hindawi.com
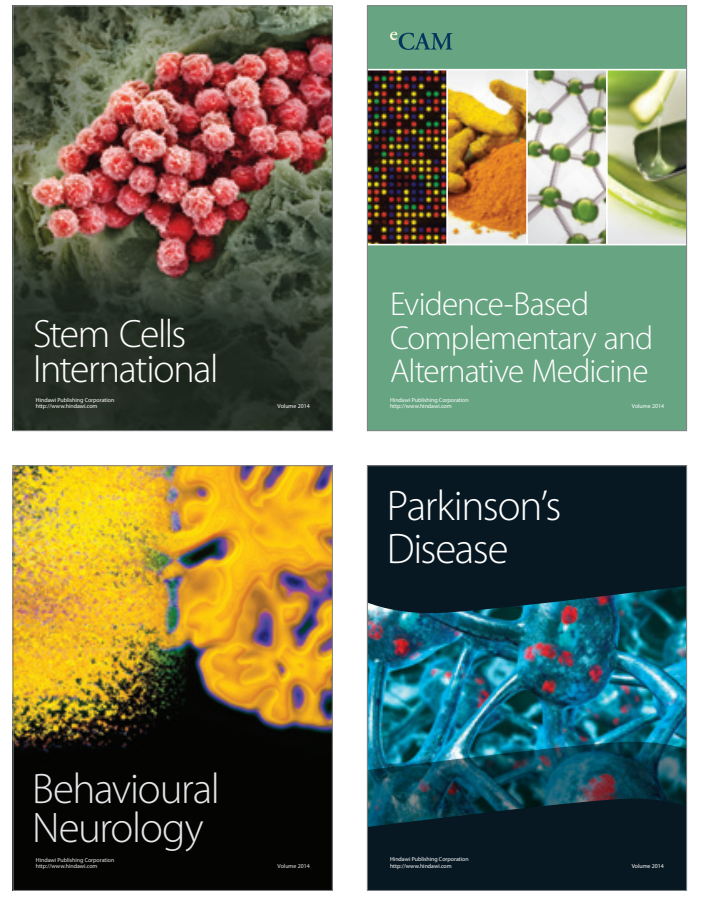
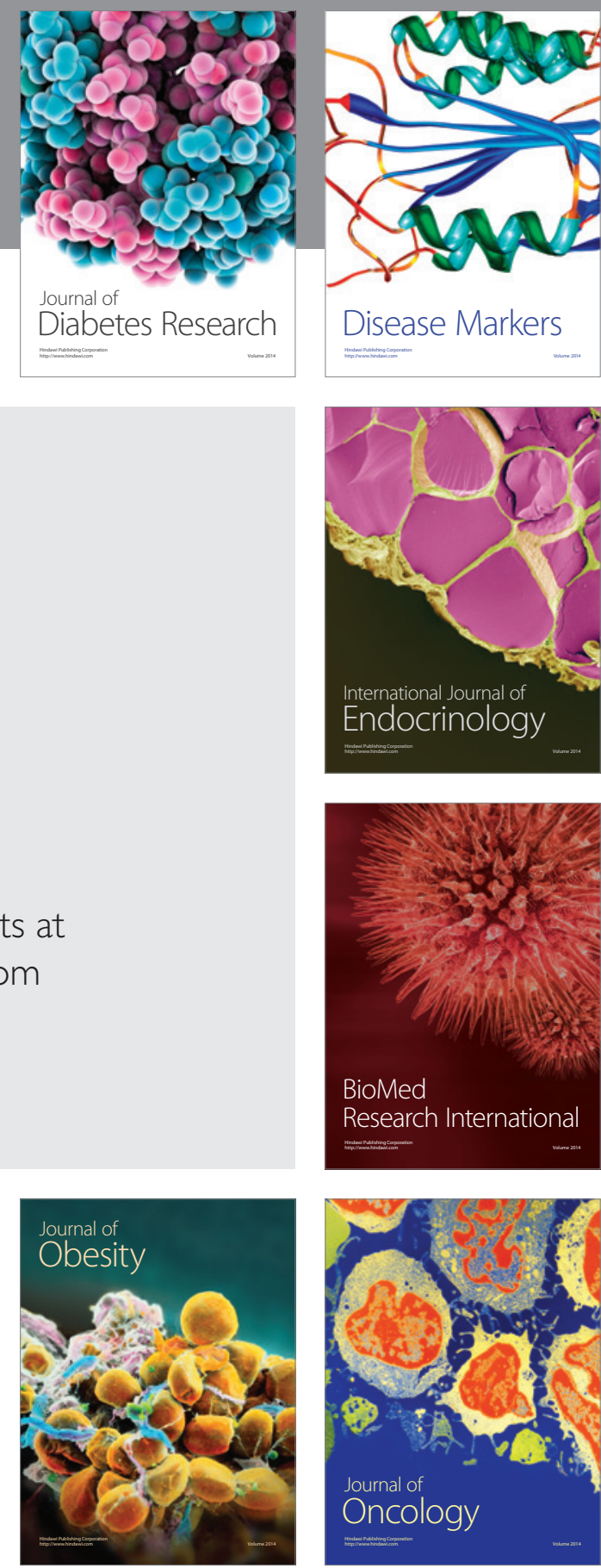

Disease Markers
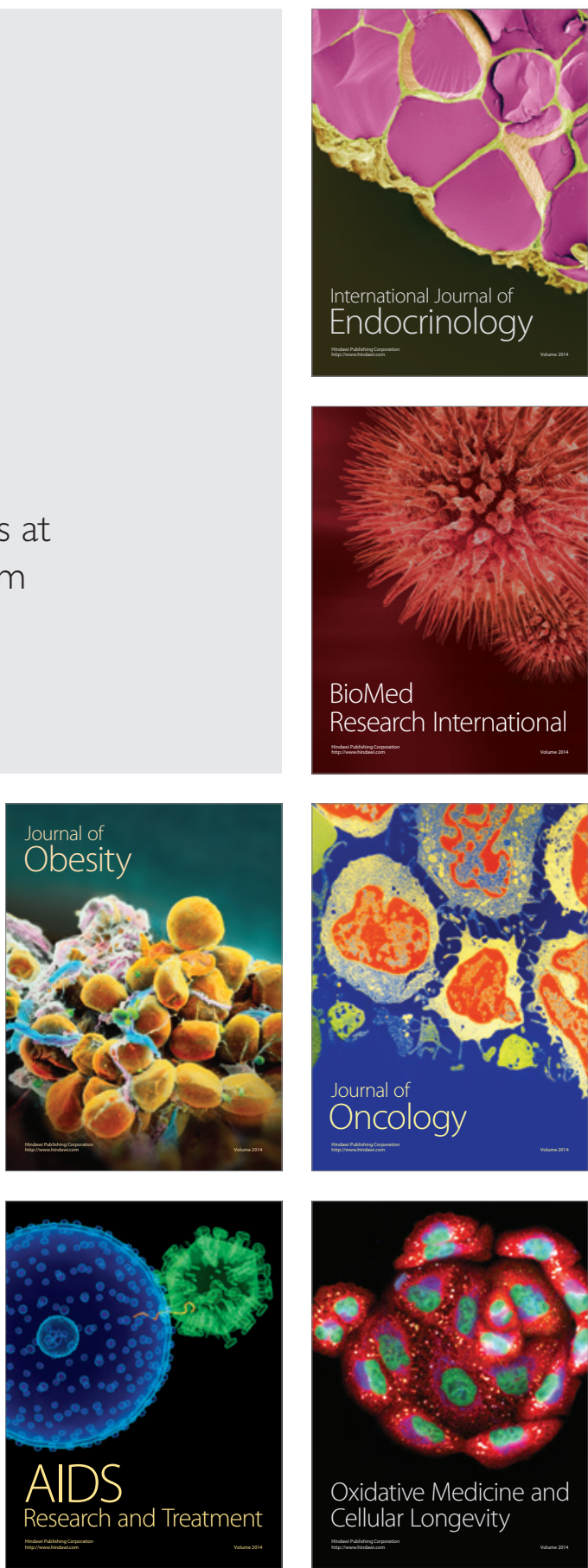